\title{
Effects of Reintroduction of European Beaver in the Lowlands of the Vistula Basin
}

\author{
Wirgiliusz ŻUROWSKI \& Bogdan KASPERCZYK
}

Żurowski W. \& Kasperczyk B., 1988: Effects of reintroduction of European beaver in the lowlands of the Vistula basin. Acta theriol., 33, 24:325-338 [With 4 Tables \& 2 Figs]

European beaver, Castor fiber (Linnaeus, 1758) was reintroduced into the lowland part of the Vistula basin in 1975-1985. The animals originated from the river basins of Neman and Pregola rivers or came from a beaver farm. Sixteen small populations were formed, composing 2 to 11 (mostly 4) families. The total number of the reintroduced beavers was 168 , and in the first year they set up 64 sites. The loss of animals in the first year after the reintroductions amounted to $14 \%$. Descedant sites began to appear after 3-4 years. Up to the end of 1985, 44 new colonies arised in the regions of reintroductions, mainly in the lakelands of Northern Poland, where the annual increase in the number of sites was $20 \%$ in the reintroduced families. A high birth-rate with a mean of 1.9 young per litter was observed. The suitability of beavers raised in farm for reintroduction was confirmed. The reintroduction in the Vistula basin should ensure formation of a large compact beaver population.

[Research Station of Polish Acad. Sci., Popielno, 12-222 Wejsuny Poland]

\section{INTRODUCTION}

In the first half of the 19th century European beaver, Castor fiber (Linnaeus, 1758) became extinct in the Vistula River basin. Fig. 1 shows the years and places where the last beavers were caught, killed or observed. In the 1940 s beavers appeared again in this river as a result of planned reintroduction (Fig. 1). The development of this population was, however, not sufficiently dynamic that a permament maintenance of the species on the tributaries of the Vistula under passive protection could be predicted.

In Europe in the last 50 years the populations of beaver were restored owing to reintroduction in Sweden, Norway, Finland and the USSR, and the numbers of animals raised to a level requiring controlled restriction (Lavsund, 1977; Myrberget, 1977; Lahti, 1977; Žarkov, 1969). In France, Switzerland, the GDR, Austria and the FRG reintroduction is being used for extending the European beaver range or for maintenance of small insular populations (Weinzierl, 1973; Reichholf, 1976; Erome, 1982; Heidecke, 1983; Schneider, 1985; Stocker, 1985). In Poland the 
need arose of reintroduction of beaver in the river basin of the Vistula for creating a basis for permanent maintenance of the species.

The purpose of this work was to form a network of small beaver populations along the Vistula in the lowland part of its basin by reintroduction of the animals caught in the river basins of the Neman and the Pregola (where beaver populations had the highest growth rate, Żurowski, 1973) or raised on animal farm.

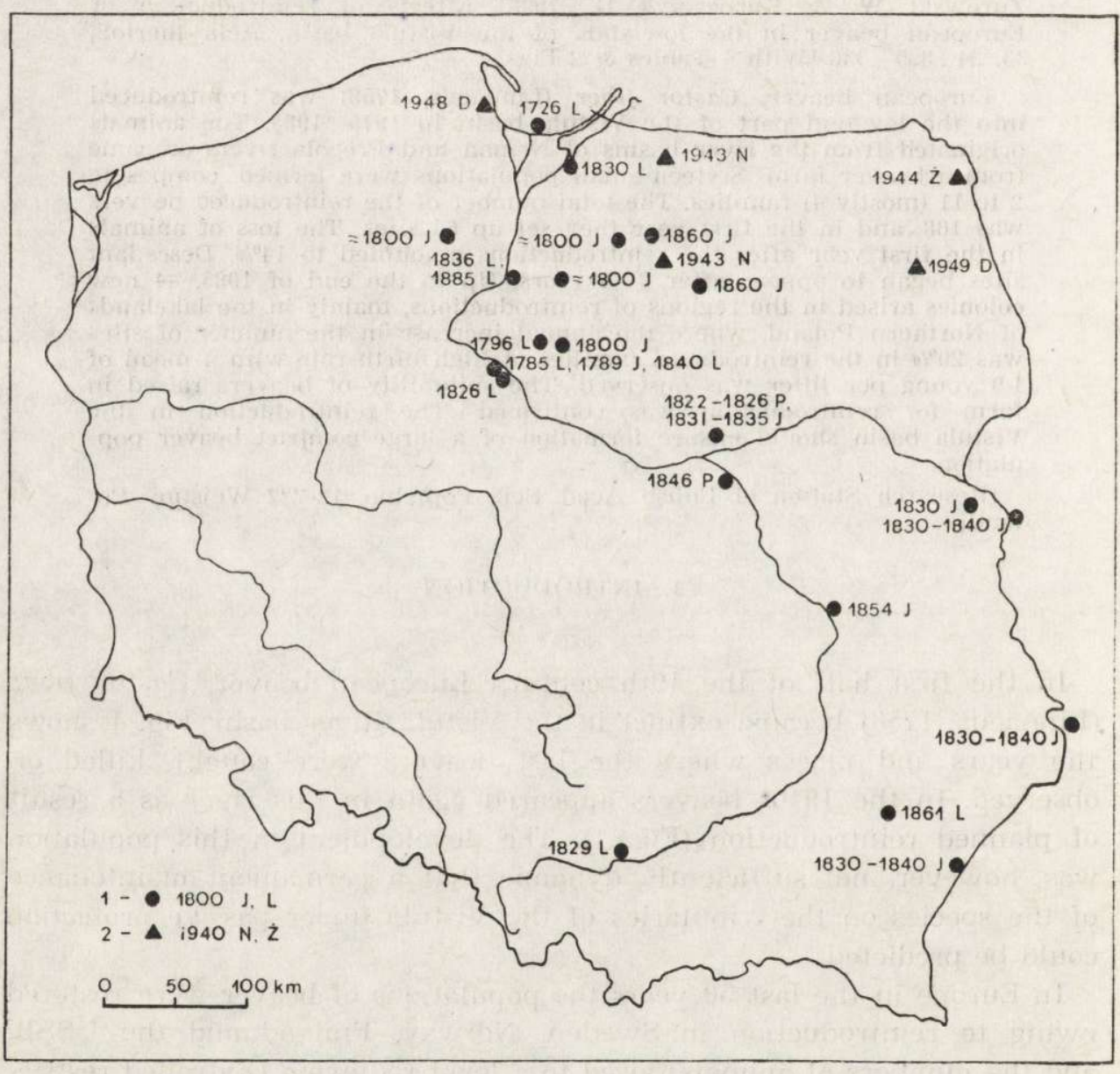

Fig. 1. Places where the last beavers had been caught, killed or observed in the Vistula basin and of reintroductions and imigrations in the 1940s. 1 - place and year of observation of beaver according to: J - Janota (1876), L - Linstow (1908), P - Pietruski (1846); 2 - place of reintroduction of beavers in the 1940 s according to: D - Dehnel (1958), N - Nowak \& Zurowski (1986) and imigration according to: Ż Z Żurowski (1983). 


\section{STUDY AREA, MATERIAL AND METHODS}

Reintroductions were carried throughout the whole river basin of the Vistula, from the Masurian and Pomeranian Lakelands in the North, to the Carpathian Mountains in the South. Before the introduction of beavers in a chosen region the agreement had to be obtained from a competent Province Office. No such agreement was obtained for reintroduction of beavers in the provinces Radom, Lublin and Tarnobrzeg. Fragments of brooks and small rivers little changed by man and rich in willow and alder thicket were chosen for the settlement of these small populations. Less attention was given to the purity of water. The animals were, however, never settled at waters beyond class III of purity (Szczęsny, 1982). Small populations consisted of 2 to 11 pairs (mostly 4) released at distances from 2 to $20 \mathrm{~km}$ each from the others. The greatest distance between the nearest populations was not exceeding $100 \mathrm{~km}$ in straight line. The purpose of this distribution was to give the migrating young animals the chance to find partners and to establish new colonies. The protection of the newly set up or already existing beaver sites in the areas held on lease by Hunting Groups was the responsibility of the Polish Hunting Association which employed an adequate number of gamekeepers for this purpose.

The beavers for resettlement were caught, prepared for reintroduction and realesed in new areas by the methods described by Żurowski (1979). In the years 1975-1985, 168 beavers were settled in the lowland part of the Vistula basin. 149 animals originated from the river basins of the Neman and the Pregola rivers, and 11 animals derived from the experimental beaver farm at Popielno.

The results of the reintroduction were recorded by annual inventories of colonies, collecting informations on deaths or catching of beavers and detection of young animals in selected beaver sites (Żurowski, 1979).

\section{RESULTS}

\subsection{Losses and Migrations After Reintroduction}

Table 1 lists the regions where small beaver populations were settled, the number of released animals in the particular populations, and the number of beaver families at the end of 1985 . Fig. 2 presents the distribution of reintroduction regions.

Table 2 presents the losses of animals in particular regions. Probably, this list is not complete, but it makes possible an estimation of effect of reintroduction. Losses caused by stress during catching, transportation and leaving the animals under new conditions were very low. These losses would not have any significant effect on the development of these small populations, if losses due to poaching were not superimposed on them. Out of 8 beavers killed by poachers 5 died within one year after reintroduction. Probably, the column "cause unknown" contains mostly beavers killed by poachers. The total losses in the first year after reintroduction were about $14 \%$ ( 22 animals) of the released beavers. 


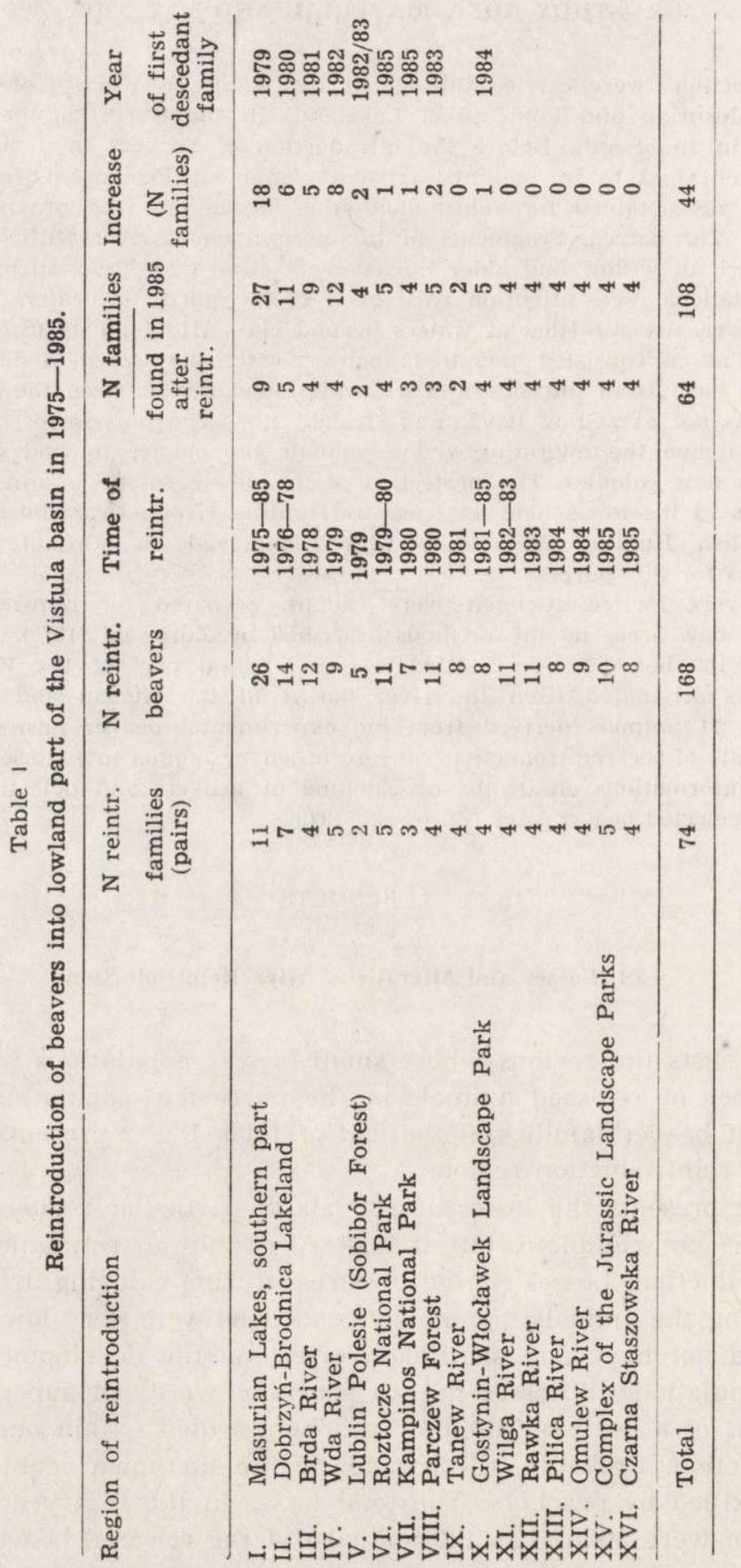


The released animals remained in the regions of reintroduction. Out of 74 reintroduced pairs in 4 cases only (about 5\%) far-reaching wandering of animals occurred, over $50 \mathrm{~km}$ from the site of their release.

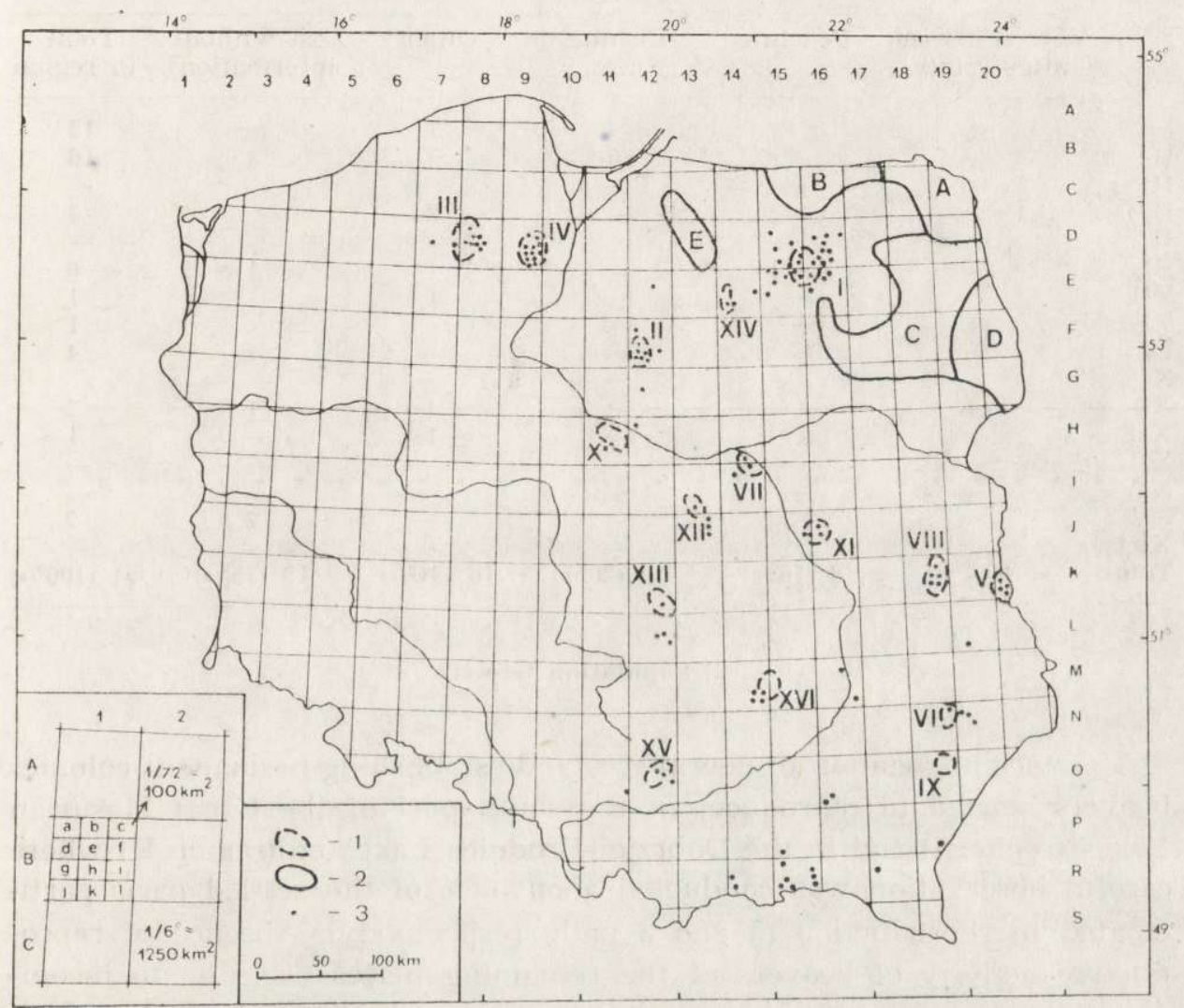

Fig. 2. Distribution of European beaver populations and sites in the Vistula basin and in the north-east Poland in 1985. 1 - regions of reintroduction in 1975-1985 in lowland part of the Vistula basin (names of regions in Table 1);2 - natural and reintroduced in the 1940 s and 1950 s populations: A - population of Suwalki Lakeland (Żurowski, 1983), B - population of Prussian Lowland (Żurowski \& Siuda, 1985), C - population of Biebrza Valley (Źurowski, 1982), D - population of Białystok Region (Pucek, 1972), E - population of Pasłęka Valley (Nowak \& Zurowski, 1986); 3 - beaver sites in the Vistula basin in end 1985.

The others remained in situ or moved from 1 to $20 \mathrm{~km}$. All far wanderings occurred when the animals were released at greater rivers - (Drwęca, Wieprz, Tanew). 


\section{Table 2}

Losses of beavers (in numbers of animals) in the reintroduction regions (see Table 1 for names of the regions). Information about losses were obtained in interviews with the local fishermen, hunters etc.

\begin{tabular}{|c|c|c|c|c|c|c|}
\hline \multirow{2}{*}{ Region } & \multicolumn{6}{|c|}{ Losses of beavers } \\
\hline & $\begin{array}{l}\text { Within a week } \\
\text { after reintr. }\end{array}$ & Poaching & $\begin{array}{l}\text { Fishing } \\
\text { nets }\end{array}$ & Other & $\begin{array}{l}\text { Lost without } \\
\text { information }\end{array}$ & $\begin{array}{l}\text { Total } \\
\text { in region }\end{array}$ \\
\hline I & - & 4 & 4 & 7 & - & 15 \\
\hline II & - & 4 & 6 & 3 & 3 & 16 \\
\hline III & - & - & - & - & - & - \\
\hline IV & 1 & - & - & 2 & - & 3 \\
\hline $\mathrm{V}$ & - & - & - & - & - & - \\
\hline VI & 1 & - & - & 1 & 4 & 6 \\
\hline VII & - & - & - & 1 & - & 1 \\
\hline VIII & 1 & - & - & - & - & 1 \\
\hline IX & - & - & - & - & 4 & 4 \\
\hline $\mathrm{X}$ & - & - & - & - & - & $\longrightarrow$ \\
\hline XI & 1 & - & - & 1 & 1 & 2 \\
\hline XII & - & - & - & 1 & - & 1 \\
\hline XIII & - & 一 & - & - & - & - \\
\hline XIV & - & - & - & - & - & - \\
\hline$X V$ & - & - & - & - & 2 & 2 \\
\hline XVI & $\overline{(80 \%)}$ & $8 \overline{(16 \%}$ & $10 \overline{(20} \%)$ & $\overline{(210 / 0)}$ & - & $\overline{-1}$ \\
\hline Total & $4(8 \%)$ & $8(16 \%)$ & $10(20 \%)$ & $16(31 \%)$ & $13(25 \%)$ & $51(100 \%)$ \\
\hline
\end{tabular}

\subsection{Population Growth}

After acclimatization in new places and establishing permanent colonies beavers started to reproduce. In the south part of the Great Masurian Lakes (region I) and in the Dobrzyń-Brodnica Lakeland (region II) where careful observation was conducted about $60 \%$ of the settled paris participated in reproduction ( 5 and 3 pairs respectively). Absence of reproductive activity of beavers at the remaining places was due to incompleteness of pairs or old age of the animals. In some cases in which the sex of the dead animal could have been determined, the pair was completed by bringing an animal of the suitable sex (Great Masurian Lakes, region I, 3 cases; the Wilga River, region XI, 2 cases; Roztocze National Park, region VI, one case). The annual increase in the number of beaver sites was difficult to establish in view of short time of functioning of the settled populations, but in the populations with a history of many years in the Lake Districts (regions I, II, III, IV) this increase was about $20 \%$ yearly. The first descedant colonies appeared usually in the 3 rd or 4 th year after reintroduction (Table 1).

Tape-recorder detection of births in all beaver logdes in the Great Masurian Lakes (region I) and in the Dobrzyń-Brodnica Lakeland (region II) showed that 39 litters comparised 72 live born kits. The mean number of newborns per litter was 1.9 . 


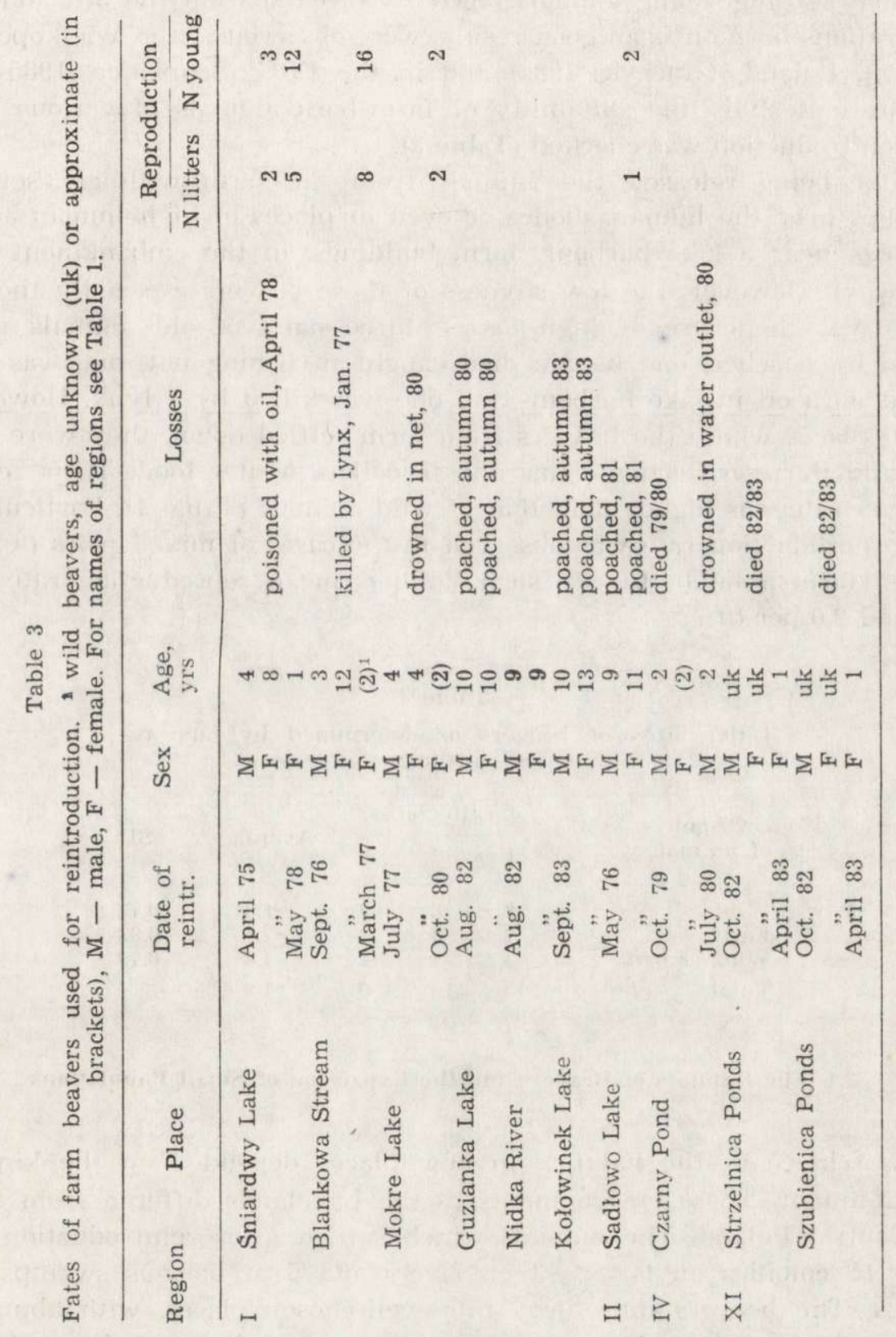




\subsection{Suitability of Beavers from Animal Farm for Reintroduction}

When settling young animals (aged 2-4 years) from the $3 \mathrm{rd}$ and 4 th generations born on farm good results were observed in the Wielkopolska Region, Poland (Graczyk, 1984) and in the FRG (Schneider, 1985). In the present study the suitability of farm-born animals of various ages for reintroduction was checked (Table 3).

After being released the animals from the farm willingly set up colonies near the human abodes or even in places of high human activity (e.g. near a lake harbour, farm buildings, in the embankment of a highway). However, the low shyness of these beavers especially the old ones, was the cause of high losses: three pairs of old animals were killed by poacher, one female died caught in fishing net, one was poisoned with oil in lake harbour, and one was killed by a lynx. However, in all places where the beavers from farm settled down, they were able to build burrows, logdes, dams and to collect winter food. Their reproduction rate was higher than that of wild animals (Table 4). Particularly high reproduction rate was observed in the cases of mixed pairs (a wird and a farm animal). In two such families mean reproduction rate was 2.1 and 2.0 per litter.

Table 4

\begin{tabular}{|c|c|c|c|c|c|}
\hline \multirow{2}{*}{$\begin{array}{c}\text { Origin } \\
\text { of animals }\end{array}$} & \multicolumn{3}{|c|}{ Litter size } & \multirow{2}{*}{ Average } & \multirow{2}{*}{ SD } \\
\hline & 1 & 2 & 3 & & \\
\hline Wild & 9 & 8 & 4 & 1.8 & 0.77 \\
\hline Farm & 2 & 3 & 3 & 2.1 & 0.83 \\
\hline Wild $\times$ Farm & 4 & 4 & 2 & 1.8 & 0.79 \\
\hline Total & 15 & 15 & 9 & 1.9 & \\
\hline
\end{tabular}

\subsection{The Habitats of Beavers and the Expansion of Small Populations}

The choice of the habitats in new places depended on the kind of environment. These environments in the Lakelands differed from those in Central Poland. The animals which settled after reintroduction formed 15 colonies on lakes, 43 on rivers and 6 at various swamps and ponds. The beavers introduced into well-chosen places, with abundant winter food, on lakes or swamps, usually never left these places. At the end of 1985 in all reintroduction regions 20 beaver sites were found on lakes, 75 on rivers and 13 in swamps. This shows evidently that wherever 
habitat could be chosen, rivers were preferred, since the number of colonies on rivers increased by $74 \%$, on swamps by $45 \%$, and on lakes (least preferred) by $25 \%$. Beavers willingly chose sites with high banks where they could live in burrows. They built logdes, in 34 sites $(31 \%)$ and dams in 11 sites $(10 \%)$ only. In the Lakelands they preferred the streams connecting lakes. Under suitable conditions the descendant colonies were found not far from the parental ones, from several to about $20 \mathrm{~km}$. The choice of a site for a new colony was influenced evidently by abundance of winter food.

In the Dobrzyń-Brodnica Lakeland (region II) and in the Polesie Lubelskie (region V), in the sites where the waterways had been disrupted in the drought years 1982,1983 , and 1984 , beavers set up descendant colonies near the parental ones. The distances between colonies were from 30 to $100 \mathrm{~m}$, still in the neighbouring colonies tape recording demonstrated presence of newborn animals. Under such enforced conditions the beavers suppressed their territoriality and set up large colonies of related families. In April 1984 wandering of a beaver over a watershed was observed in region $\mathrm{V}$.

A high increase in number of colonies was observed only in the reintroduction regions where the beavers were released in the first years of this action (regions I, II, III, IV). In these regions the density of the beaver sites was initially high, and an evident increase of the area occupied by beavers occured in the Great Masurian Lakes (region I) where the animals had been released earliest. Within 7 years this population increased its area by nearly $3000 \mathrm{~km}^{2}$. Only in the Dobrzyn-Brodnica Lakeland (region II), where the animals could migrate along two greater rivers Drwęca and Skrwa, besides increased density of colonies in the reintroduction area, tree descendant beaver sites were set up abut 20 and $50 \mathrm{~km}$ from the parental ones.

\section{DISCUSSION}

According to Lavsund (1977) and Lahti (1977), the restoration of the beaver population to a state requiring restriction of futher growth lasted in Sweden and Finland about 40 years. In these countries small numbers of animals were used for reintroduction, and they were scattered over large areas. In the USSR, where large groups of 50 to 100 animals were used for reintroduction, this period was shortened to about 20 years (Žarkov, 1969). In this study the results of reintroduction in the earliest populated areas (I, II, III, IV) suggest that the method of settling small numerous populations at rather small distances may reduce considerably 
the time of restoration of a large population, even in the particularly difficult ecological conditions of modern Poland. The validity of the method of using small populations instead of scattered single pairs is confirmed by the observed high rate of losses among the animals after reintroduction $(14 \%)$. These losses were higher than during catching the animals. Out of the whole group of 245 caught beavers only 13 animals $(5 \%)$, were lost during catching and transportation (the procedure of a major stress for wild animals). Out of these $50 \%$ were young animals aged about 6 months, while after reintroduction usually adult animals died. The introduction of small groups of animals into a new area made it possible, in case of loss of one partner from a pair, to fill the loss with young animals from neighbouring colonies. Similarly, the fact that some of animals failed to reproduce was not discrediting the role of small populations. It seems that the losses had no big effect on population growth. This was evident in the Great Masurian Lakes (region I) where the recorded losses were considerable.

The beaver populations of the Great Masurian Lakes, Dobrzyn-Brodnica Lakeland, the $\mathrm{Wda}$ and the Brda rivers (regions I, II, III, IV) in northern Poland were growing quickly. This was due to good environmental conditions and to acceptance of beavers by the local people. The conditions were significantly worse in the middle part of the Vistula basin, especially in the Roztocze National Park, Kampinos National Park, Parczew Forest and the Tanew river (regions VI, VII, VIII, IX). Traditional poaching affected the rate of growth of beaver population there. The example of the Sobibór Forest Inspectorate (region V) shows how important is a well organized protective service. This region resembles regions VIII and VI (physiographic features) but the rise in the number of beaver sites was $100 \%$ in a short time.

The active protection of beaver in Poland had also a positive effect on the earlier populations A, B, C, D (Fig. 2). During the last 8 years these populations considerably extended their ranges and the chances for contacts between various populations increased. It might be expected that a large population will develop in the whole territory of north Poland Lakeland from small populations introduced into the regions of the Great Masurian Lakes, Dobrzyn-Brodnica Lakeland, the Brda, the Wda and the Omulew rivers (regions I, II, III, IV, XIV), and the population E. This large population could join the population in the Wielkopolska region (Graczyk, 1984) through the Bydgoszcz Canal.

The present study confirmed also the suitability of farm beavers, especially the young animals, for reintroduction (Graczyk, 1984; Schneider, 1985). A high mortality of the reintroduced old farm animals and their low reproductive efficiency (Table 2) suggest that the old wild 
animals should not be used for reintroduction. Unfortunately, there is no method for accurate determination of age of the caught adult animals and their selection for reintroduction.

Acknowledgment: The authors acknowledge gratefully the help of $\mathrm{Mr}$ Bohdan Czeszko and $\mathrm{Mr}$ Roman Bratny in obtaining of technical support indispensable for work, and deep gratefulness is owed also to all members of the Polish Hunting Association who participated in the organization of introductions and protection of new beaver colonies in Poland. The study was carried out as part of the problem MR II. 19.

\section{REFERENCES}

1. Dehnel A., 1958: Zamki na wodzie. Państwowe Zakłady Wydawnictw Szkolnych: $1-75$. Warszawa.

2. Erome G., 1982: Contribution a la connaissance éco-éthologique du Castor (Castor fiber) dans la vallée du Rhône. Ph. d. Theses L'universitá Claude Bernard-Lyon: 1-284. Lyon.

3. Graczyk R., 1984: Ekspansja bobra w Wielkopolsce. Przyr. pol., 4: 3-6.

4. Heidecke D., 1983: Biber - Wiederansidlungen auf population ökologischer Grundlage. Säugetierkundl. Inf., 7: 19-29.

5. Janota E., 1876: Obrazki z życia zwierząt: bóbr, żubr. Czytelnia Staropolska: 1-76. Kraków.

6. Lahti S., 1977: Den finska bäverns förekomsthistoria och nutida utbredning. Proc. Nordic Symp. on the Beaver, 1975: 19-22. Stockholm.

7. Lavsund S., 1977: Bäverns utbredningshistoria och nuverande förekomst i Sverige. Proc. Nordic Symp. on the Beaver, 1975: 8-12. Stockholm.

8. Linstow O., 1908: Die Verbreitung des Bibers im Quartar. Mus. Nat. Heimatk. Magdeburg, 1(4): 211-387.

9. Myrberget S., 1977: Bäverns utbredelse i Norge omkrig 1975. Proc. Nordic Symp. on the Beaver, 1975: 13-18. Stockholm.

10. Nowak E. \& Zurowski W., 1986: Jeszcze raz o pochodzeniu bobrów w dolinie rzeki Pasłęki. Chrońmy Przyr. ojcz., 1: 72-77.

11. Pietruski v. Siemuszowa S., 1846: Uber den polnischen Biber. Arch. Naturgesch., 1: 186-189.

12. Pucek Z., 1972: Rozprzestrzenianie się i stan ochrony bobra europejskiego na Białostocczyźnie. Chrońmy Przyr. ojcz., 1: 28-36.

13. Reichholf J., 1976: Zur Wiedereinbürgerung des Bibers (Castor fiber L.). Natur. u. Landsch., 51: 41-44.

14. Schneider E., 1985: Erfahrung zum Management lokaler Vorkommen des Bibers Castor fiber L. in der Bundesrepublik Deutschland. Z. Angew. Zool., 72: $191-203$.

15. Stocker G., 1985: Biber (Castor fiber L.) in der Schweiz. Probleme der Wiedereinbürgerung aus biologischer und ökologischer Sicht. Eingenössische Anstalt für das forstliche Versuchswesen Berich., 274: 1-149. Brimensdorf - Basel.

16. Szczęsny T., 1982: Ochrona przyrody i krajobrazu. PWN: 24-37. Warszawa.

17. Weinzierl H., 1973: Projekt Biber. Wiedereinbürgerung von Tieren. Kosmos Bibliothek Nr. 279. Stuttgart.

18. Žarkov I. V., 1969: Itogi rasselenija rečnych bobrov v SSSR. Tr. Voronež. Gos. Zap., 16: 10-51. 
19. Żurowski W., 1973: O skuteczną ochronę bobrów. Chrońmy Przyr. ojcz., 2: $30-39$.

20. Zurowski W., 1979: Preliminary results of European beaver reintroduction in the tributary streams of the Vistula river. Acta theriol., 24: 85-91.

21. Zurowski W., 1982: Rozmieszczenie i ekologia bobra europejskiego Castor fiber w pradolinie Biebrzy. Chrońmy Przyr. ojcz., 1-2: 18-26.

22. Zurowski W., 1983: Rezerwat ostoja bobrów Stary Folwark. Chrońmy Przyr. ojcz., 3: $47-54$.

23. Żurowski W. \& Siuda A., 1985: Ochrona bobra w rejonie Kanału Mazurskiego. Parki nar. Rez. Przyr., 6: 57-69.

Received 16 August 1985, Accepted 30 March 1988.

Wirgiliusz ŻUROWSKI i Bogdan KASPERCZYK

\section{REINTRODUKCJA BOBROW EUROPEJSKICH W NIZINNEJ CZESCI DORZECZA} WISEY

\section{Streszczenie}

W latach 1975-1985 w nizinnej części dorzecza Wisły przeprowadzono reintrodukcję bobrów europejskich, Castor fiber Linnaeus, 1758 pochodzących z odłowów głównie na Pojezierzu Suwalskim oraz z hodowli fermowej (Tabela 1). Utworzono 16 małych populacji składających się z 2 do 11 rodzin, najczęściej 4. Wypuszczono w sumie 168 bobrów, które założyły 64 stanowiska rodzinne. Stwierdzone straty wśród wypuszczonych zwierząt do pierwszej jesiennej inwentaryzacji stanowisk wyniosły $14 \%$. Pojawienie się pierwszych potomnych stanowisk w małych populacjach miało miejsce w 3-4 roku po reintrodukcji. Do końca $1985 \mathrm{r}$. w całym terenie objętnym zasiedleniem przybyło 44 stanowiska, głównie w 4 rejonach reintrodukcji (I, II, III, IV, Ryc. 2) znajdujących się w strefie Pojezierzy północnej Polski. Roczny przyrost stanowisk w tej strefie wynosil okolo $20 \%$. Na podstawie kontroli magnetofonowej domków bobrowych w okresie rozrodu stwierdzono wysoką plenność reintrodukowanych zwierząt, wynoszącą średnio 1.9 młodego w miocie. Potwierdzono przydatność do reintrodukcji bobrów wyhodowanych na fermie.

Mniejszy przyrost populacji introdukowanych bobrów w środkowej części dorzecza Wisły miał związek $\mathrm{z}$ gorszymi warunkami siedliskowymi, jak też i trudniejszą ich ochroną. Przyjęty sposób zasiedlenia dorzecza Wisły bobrami rokuje możliwość dość szybkiego utworzenia dużej zwartej populacji bobrów, głównie w pólnocnej części Polski. 


\section{APPENDIX}

\section{List of Sites of the European Beaver Castor fiber Linnaeus, 1758} Established in Result of Reintroduction in the Vistula Basin.

This appendix contains a list of all beaver sites recorded in end 1985. These sites are coded according to the geographical grid used in Polish Red Data Book (Fig. 2). In parentheses at each site there is information on the type of beaver constructions ( $\mathrm{L}-$ lodge, $\mathrm{B}-$ burrows, $\mathrm{D}-$ dam). Abbreviations: $\mathrm{r}$. - river, 1. - lake, p. - pond or ponds.

\section{D7h Brda r., Przechlewo (B)}

i Brda r., Sąpólno (B)

D8a Zbrzyca r. (B)

d Jeleń 1. (B); Krzywce Wielkie 1. (B)

g Ostrowite 1., southern part (B); Ostrowite 1., northern part (B); Belczak 1. (B); Brda r., at autlet to Charzykowskie 1. (B)

D9e Wda r., Osowo Leśne (B)

f Wda r., Młynki (B)

h Ocypel 1. (B); Brzezianek r., Brzezianek 1. (L, D)

i Swietta Struga r. (B); Brzezianek r., at outlet of Swięta Struga r. (B); Wda r., at autlet of Brzezianek r. (B); Wda r., Wda (B); Wda r., Krępka (B)

$\mathrm{k}$ Wda r., border of voievodships Gdańsk and Bydgoszcz (B)

1 Wda r., Luby (B); Wda r., Blędno (B)

D15d Gielądzkie 1. (B)

h Kosewo (B); Lampasz 1. (B)

k Babięcka Struga r., Gant (L); Babant r. (L); R. joining Biale 1. to Gant 1. (L)

1 Krutynia r., Nowy Most (B); Krutynia r., Nowa Ukta (B)

D16e Drozdowo (B)

f Rzęśnik 1. (L)

g Marsh east of Luknajno 1. (L)

h $\mathrm{R}$. discharged to Tuchlin 1. (B)

j R. jojning Warnołty L. to Wejsunek 1. (B) (1)

k. Blankowa Struga r. (L, D); Wiskolisko l. (L, D); R. joining Warnolty 1. to Wejsunek 1. (B)

Wyszka r. (B); Białawka r. (B); Wilkus r. (B)

E12e llawka r. (B)

E14f Jowica r. (B)

g Jmulew 1. (B)

$h$ Jmulew r. (B)

E15b Lawny Lasek 1. (L); Nawiady 1. (B); Babięcka Struga r., Zyzdrój (B); Krawno Duże 1. (L)

c Zdróżno 1. (L)

g Walpusza r. (B)

E16a Nidka r. (L)

b Snopki marsh, Jagodzin (B); Snopki marsh, Radzewo (L, D) d Oko 1. (B)

F12a Grążawy marsh (B)

g Marak marsh (L, D); Marak marsh (L); Marak marsh (L, D)

j Kotownica marsh (L); Kotownica marsh (L, D); Skrwilno 1. (L)

k Pietrzyk r. (L)

G12d Skrwa r., Sierpc (B)

H11e Rakutówka r. (L)

h Rakutówka r. (L); Rakutówka r. (L); Kłótnia r., Grodno (B); Kłótnia r., Gościąż (B)

H12d Skrwa r, at outlet to Vistula r. (B)

H14k Lomna (L, D)

I13k Rawka r., Puszcza Bolimowska (B) 
I14b Zaborów (B)

c Dąbrówka (L, D); Vistula r., Lomianki (B)

J13b Rawka r., Suliszew (B)

e Rawka r., Nowy Dwór (B); Rawka r., Stara Rawa (B)

J15f Wilga r., Trzcianka (B); Wilga r., Cyganówka (B)

J16d Place "Uroczysko Huta" (B); Place "Uroczysko Ruda Talubska" (B)

K12 Luciąża r., Murowanice (B)

K18c Obadowski 1. (L)

f Prokop p. (B); Bobrówka r., Rudka (B); Bobrówka r., Jedlanka (L); Miejskie 1. (L)

K20g Koseniec 1. (L); Koseniec 1. (L)

j Brudzieniec 1. (L); Brudzieniec 1. (L)

L12e Place "Uroczysko Piotrkowski Trakt" (B)

Place "Uroczysko Slepytnica" (B); Pilica r., Lęg Rączyński (B)

L19j Wieprz r., Stężyca (B)

M14l Czarna r., Lukowa (B); Czarna r., Korzenica (B); Czarna r., Czarna (B); Czarna r., Papiernia (B)

M16e Old-river of Vistula r. near Annopol (B)

1 Mieszawa p. near Radomyśl (B)

N18c Wieprz r., Zurawica (B)

N19a Wieprz r., forest administrative unit Horodzisko (B); Wieprz r., forest i administrative unit Kruglik (B); Wieprz r,, Bondyrz (B) Chechlo r., Bolęcin (B)

O:ii Saspówka r. (B, D)

U1ze Prądnik r., Giebultów (B)

f Prądnik r., Jany (B) 